\title{
Impact of Career Counseling \& Vocational Guidance on Employment in TVET Sector
}

\author{
Muhammad Arshad (Corresponding Author) \\ Ph.D. Scholar, National College of Business Administration \& Economics, \\ 40 - E/1, Gulberg III, Lahore, Pakistan \\ Contact\# 00923214583811 \\ E-mail: arshad.tevta@gmail.com
}

\begin{abstract}
Asma Tahir
Assistant Professor

Forman Christian College University, Lahore, Pakistan

E-mail: asmatahir@fccollege.edu.pk

Mumtaz Muhammad Khan

Riphah International University, Faisalabad, Pakistan

E-mail: mumtazmkpk1@gmail.com
\end{abstract}

\author{
Abdul Basit \\ The Superior College, Lahore, Pakistan \\ E-mail: abasit_shahbaz@yahoo.com
}

Received: Jan. 30, 2018 Accepted: Feb. 26, 2018 Online published: Mar. 3, 2018

doi:10.5296/ijhrs.v8i1.12554 URL: https://doi.org/10.5296/ijhrs.v8i1.12554 


\section{Abstract}

Career counseling and employment in Technical \& Vocational Education and Training (TVET) sector is considered an important component for coping with the economic challenges, the world is facing today. This study focused on the graduates of TVET in Pakistan by collecting data from principals, employed TVET graduates and their respective employers. Our findings support our argument that career counseling is important for employment in TVET sector. We recommend empirical validation career counseling for TVET graduates in particular and all graduates in general. The career counseling needs to be explored conceptually with reference to under developed economies.

Keywords: career counseling \& vocational guidance, employment skills, labour market, TVET sector, skilled manpower

\section{Introduction}

Career counseling refers to explore the interests of students and guide them to choose their professional career keeping in view their strengths, weaknesses, resources and opportunities. Students always require professional career counselors to guide them to develop self-awareness in personal interests, skills, knowledge, potentials, weaknesses and assess occupational opportunities such as employment trends, competencies in the field, requirement of employment and job description (Kok \& Low, 2017). They also need to prepare a career plan related to their career search, goal setting, the ways to realize goals, and cultivate job-searching skills. This includes identifying potential employers, preparing résumés, preparing for interviews (Getachew et al., 2016). Every culture has its own ways of schooling its young into the world of work. Within each culture there are differences in career- and more broadly life related opportunities and constraints, depending on age, gender, ethnicity, socioeconomic status, urban rural residence, and migrant or immigrant status (Arulmani, 2011). Hence, the role of career counseling and vocational guidance services is precious in empowering students to select the best fit with their ability, interest, personality and in the long run a satisfied life (Santilli et al., 2017). This study describes the importance of career counseling for students for acquiring the employment skills.

Marilyn (2008) refers that employability is all about being capable of getting and keeping work done as per requirement. To him, employability is the capacity to deploy self-sufficiently within the labor market to realize potential through sustainable employment. Employability consists of four important elements: a person's employability assets; which consists of knowledge, skills and attitudes, deployment; which includes career management skills, and job search skills), presentation; which is concerned with job getting skills, for example CV writing, work experience and interview techniques and finally, a person's ability to make the most of his employability assets, a lot depends on his personal circumstances (for example family responsibilities) and external factors (for example the current level of opportunity within the labor market), employability of competencies such as ability, aptitude and qualities developed in context that can be applied to an occupation or career. These can be identified as employability skills. 
Survey by Association of Graduate Recruiters (AGR) has underlined the multiple shortcomings related to employability skills including: 'Softer' skills such as team-working, leadership and project management, awareness of their chosen industry sector; commercial awareness and business/organization understanding (AGR, 2007). These deficiencies might be made up by institutionalizing formal set up of career counseling and vocational guidance system at the training institutes. AGR has further stated that more than $70 \%$ of their members use competency-based selection methods and due to lacking in the softer skills, graduates find it difficult to secure their jobs.

The competencies in softer skills needs to be engendered among students not only through teaching and learning process in training institutions but also through career counseling and vocational guidance. It helps the graduates to be competitive and valuable in the labor market (Anindo et al., 2016). The job market now expects that the trainees should have know-how about the skills before taking proper admission in the institute (Tsitskari et al., 2017). This would help the trainees to learn the skills in detail and develop his interest in the early age. Workforce should be provided with the necessary requisite skills. The trainees / students who are formally guided to recognize their personal interest can exploit their potential in better way. Therefore, developed countries have appointed psychologist at primary level in their institute so that the potential can be recognized at the lower level (Mobley et al., 2017).

Career counseling and vocational guidance is interlinked with the employability of pass outs. To gain the competitive advantage, the employers are joining hands with universities and training institutes in the developed countries. These developed countries are arranging seminars, workshops and industrial tours of the students to gain awareness about the working place (Seung, 2014). This concept is vaguely implemented in most educational institutions of both governmental and non-governmental set up in under developing countries.

This study on the basis of literature and the Community of Practices (COPs) experiences proposes that the training institute may provide career counseling and vocational guidance services to their graduates so that they may demonstrate sustainability in their employability.

Technical Education and Vocational Training (TVET) plays a vital role in human resource development of the country by creating skilled manpower, enhancing industrial productivity and improving the quality of life. It equips the young people to earn sustainable livelihood in today's knowledge economy by provision of practical skills, knowhow and understanding of employment in a particular occupation, trade or group of occupations (Atchoerena et al., 2013). In modern era human resource development gives competitive edge in the global economy. So the developing countries are advised to develop their human capital to boost their economies and follow the successful practices of the developed countries. Educated workforce is an effective tool for the economic development of the country (Aluko and Aluko, 2012). The concept of career counseling and vocational guidance carries importance for the trainees of TVET sector especially in poor countries. The majority of intake in TVET sector of under developing countries belongs to lower strata of the society. Their families and belongings are not well educated to guide their siblings to assess their personal interest and scan the demand of the market. There are various skills that have to be learned. The expertise 
in these skills is found lacking among the trainees even after graduating in their respective skill sets. The majority of TVET graduates lack in communication skills because the programs lack proper emphasis on them. In the world of globalization, employers are focusing on the communication skills that help the trainees to understand the new trends through discussion with other and as team workers as well (Murgor, 2014). It has been observed that the counseling and guidance helps the students to develop career competencies and ultimately they are more motivated because it helps them to develop career identity (Meijers et al., 2013). Keeping in view the role and importance of vocational training for the economic development of the country, research is being done how to cope with the career adapt-abilities of the students with the employability skills to produce quality workforce. For this purpose, career counseling and guidance services have been introduced to guide the students to adopt the technology that suits to their interest (Brown et al., 2012; de Guzman and Choi, 2013). Enterprise based trainings including entrepreneurial, communication, financial and leadership skills led the TVET graduates to start their own small business which is another bright aspect of TVET system that can be a valuable source for the economic growth of a country (Asunsung et al., 2013). Career Counseling in this perspective is important and needs more focus.

In Pakistan, there are several categories of training institutes imparting skills in various capacities. There are technical and vocational centers, commerce institutes, apprenticeship centers, production units (service centers) and colleges/universities for general education. Unfortunately, the concept of career counseling and vocational guidance has not been formally institutionalized (Bilal and Malik, 2014). The severity of the problem and inadequacy of relevant information among TVET sector students have encouraged the undertaking of this study. The aim of this study is to assess career guidance among trainees of Punjab Technical Educational and Vocational Training Authority. For understanding the existing level of career counseling and vocational guidance, conduct of a pilot study is useful as a determining factor before proceeding further into research.

A pilot study is a small-scale form as well as the specific pre-testing of a particular research of a planned study that is carried out with a small group of participants similar to those who would be selected later in the larger scale study (Doody and Doody, 2015). This study helps the researchers to practice and assess the effectiveness of their planned data collection and analysis techniques. Furthermore, on the basis of results, the researchers can sense the possible anticipated problems, resulting the changes are made before the large-scale study is undertaken (Hundley and van Teijlingen, 2002; Kim, 2011; Leon et al., 2011). Two pilot studies are conducted prior to the large-scale study. So the objectives of these two pilot studies are conducted to assess the level of system of career counseling and vocational guidance at colleges / institutes in TVET sector in Pakistan.

\subsection{First Pilot Study}

The first pilot survey is conducted in a technical institution of Punjab TEVTA. Out of 120 final year $\left(3^{\text {rd }}\right.$ year $)$ students of DAE Electrical and Mechanical Technologies whose ages are between 16-18 years, two samples comprising of 20 students each are selected. A career 
assessment inventory tool is downloaded from internet and customized by the researcher with the help of TVET experts. There are various statements divided into different groups i.e. Group A, Group B etc. and every group defines one category of different types of personalities like technical person, accountant, teacher, social worker, actor etc. Furthermore, every statement is assigned a particular number like 1,2, 3 etc. and the students are asked to mark the statements in every group that suits to their interest and personalities. Finally numbers of statements marked by the students are counted and then the students are informed about their personalities on the basis of results. It is surprising to see that the personalities of majority of them did not match with their current studies. The mismatch between their personalities and career choices indicates scarcity of career counseling and vocational guidance system in Pakistani education system at different level.

To dig out the severity of this issue, a simple questionnaire is developed by the researcher with the assistance of TVET expert to analyze the efforts made by the TVET institution for creating awareness among the students related to their future working place. The questionnaire comprises the questions pertaining to the efforts made by the TVET institution administration for preparing their trainees in line with the requirement of the job market.

The analysis of the results suggests that there is no formal guidance system at institution level to keep them abreast of the requirement of job market. Most of them have poor communication skills. They had received no soft skills training (CV writing \& Interview skills etc.). There is no proper system of career counseling for the students that could help them in selecting the right trade / technology according to their aptitudes, at the time of admissions. Industrial visits are not arranged for students' to their relevant industries to prepare them beforehand for their working environment. During their three years of study, only one industry visit is arranged. There is no on job training system for the students. No industrial training or visits of instructional staff to the industry are arranged and furthermore, no job fairs / workshops / seminars are arranged at the institutional level to create awareness among the students. There is no strategy or commitment on the part of the institutions with regards to maintenance of a strong liaison with the industry.

\subsection{Second Pilot Study}

In the second pilot study, the researcher is part of an interview team at the office of Overseas Employment Corporation, based in Lahore city of Pakistan. The interviews are conducted by Mr. Qasim Avais Gillani, General Manager, Al-Wazeer, Travel \& Tourism (Group of Companies), Saltnat of Oman for the recruitment of various skilled workforces. 100 graduates of different trades / technologies appeared against the demand of 47 posts. The objective of the study is to observe and check whether the TVET institutes of Pakistan have equipped their graduates with required skills in all aspects as demanded by international market.

During the interviews, the researcher has observed that they have failed to present themselves as professionals and are lacking in interpersonal, communication and soft skills. The interviewees are found to be non-impressive and have no understanding of their future work environment by the recruiting employers. They seem to have outdated / obsolete knowledge 
and are not up to date with reference to the market demands. They gave an impression of being unenthusiastic, non-committed and without any drive for learning the skills. From technical skills point of view they had lack of understandings of drawings, which are supposed to be essential components of their course work. Furthermore, they are also lacking in analytical skills in practical problems.

The aforementioned issues indicate that there is lack of institutionalized mechanism of career counseling and vocational guidance system in the TVET sector of Pakistan. The students are not given the exposure of job market and are not equipped as per national and international market demand. The findings of two pilot studies encouraged the researcher to move ahead and dig out the real situations of career counseling and vocational guidance system in TVET sector of Pakistan.

\section{Methodology}

The objective of this research is to explore and assess the present career counseling and vocational guidance system in TVET sector in Pakistan. To evaluate this concept in depth, the relevant stakeholders of TVET sector including the TVET graduates who are working in local industry, the Principals of concerned technical institutes and the respective employers who had provided opportunities to the graduates in their industries are part of the population. The employed graduates are selected / targeted in order to evaluate the exposure of TVET learners related to industrial environment during their learning/course period.

This research focuses on the feedback of employers and principals, which is compulsory to perceive the level of efforts made by them to turn the TVET graduates into a quality skilled workforce. To achieve this end, the study is carried out through questionnaire based surveys, with three groups of respondents, viz., Principals of TVET institutions, TVET graduates and the industrial employers.

\subsection{Population}

Table 1. Summary of TEVTA Graduates in Punjab

\begin{tabular}{c|l|c|c|c|c|c|c|c|c}
\hline S\# & $\begin{array}{c}\text { Technology } \\
\text { (DAE) }\end{array}$ & $\begin{array}{c}\text { No. of } \\
\text { Institutions }\end{array}$ & 2012 & 2013 & 2014 & 2015 & 2016 & Total & $\begin{array}{c}\% \text { age } \\
\text { of the } \\
\text { Total }\end{array}$ \\
\hline 1 & Chemical & 4 & 625 & 561 & 804 & 1018 & 863 & 3,871 & 6 \\
\hline 2 & Civil & 6 & 984 & 1222 & 2441 & 4059 & 6642 & 15,348 & 21 \\
\hline 3 & Electrical & 7 & 3126 & 3805 & 5200 & 5687 & 5927 & 23,745 & 33 \\
\hline 4 & Electronics & 7 & 2528 & 3226 & 3618 & 3254 & 2503 & 15,129 & 21 \\
\hline 5 & Mechanical & 6 & 1077 & 2187 & 2886 & 3484 & 3701 & 13,335 & 19 \\
\hline
\end{tabular}

Source: Punjab Board of Technical Education, Pakistan

The population of the study is 200,000 skilled graduates annually produced by TVET Sector consisting of total 396 institutions. These institutions include 30 technical and 366 vocational training institutions in the province. Thirty Govt. College of Technologies working under the administrative control of Punjab TEVTA are providing technical skills in more than 30 different technologies. The graduates of chemical, civil, electrical, electronics and mechanical 
technologies are targeted keeping in view their highest enrollment during the last five years. There are 30 DAE institutions in all, which have produced almost $6 \%$ of DAE (Chemical), $21 \%$ of DAE (Civil), $33 \%$ of DAE (Electrical), $21 \%$ of DAE (Electronics) and $19 \%$ of DAE (Mechanical) (Table 1).

This study targeted the graduates, principals and industries related to the 30 Government Colleges of Technologies (GCTs) and five associated engineering technologies. The study population consisted of the three groups; Group I: Principals of all the GCTs, Punjab (List of institutions; Group II: All Punjab TEVTA students who had graduated during the five years period of 2012-2016, in five technologies falling under the category of Diploma in Associate Engineers (DAEs), who are also employed in the industries are the population; Group III: Industrial employers in Punjab, i.e. HR Managers of all the industries where the GCTs' graduates are employed.

To ensure representation of all the technologies in respondent groups, a Multi-Framed Stratified Random Sampling technique is adopted for sample selection. In the stratified probability sampling technique, the target population is separated into "mutually exclusive, homogeneous segments (strata), and then a simple random sample is selected from each segment (stratum)". The samples selected from the assorted strata are subsequently combined into a single sample. Following the technique, the relevant population is divided into five subgroups or strata based on five technologies including Chemical, Civil, Electrical, Electronics and Mechanical.

Thereafter three sampling frames for five technologies are formulated. Frame-1 comprises of lists of all the institutions offering different DAEs, Frame-2 lists of employed graduates in each technology and Frame-3 lists of all the industries where these graduates are employed.

\subsubsection{Sample Size Determination for the Three Groups/Frames}

Table 2. Sample of Employees/TVET Graduates/ in Five Technologies

\begin{tabular}{c|l|c|c|c}
\hline S\# & $\begin{array}{l}\text { Trade (DAE) of } \\
\text { Employee } \\
\text { Graduates }\end{array}$ & $\begin{array}{c}\text { Population of } \\
\text { Graduate Employees } \\
\text { in the trade } N_{h}\end{array}$ & Sample SD/s & $\begin{array}{c}\text { Stratum Samples } \\
n_{h}\end{array}$ \\
\hline 1 & Chemical & 047 & 2.4 & 3 \\
\hline 2 & Civil & 251 & 1.3 & 9 \\
\hline 3 & Electrical & 516 & 1.2 & 18 \\
\hline 4 & Electronics & 048 & 2.1 & 4 \\
\hline 5 & Mechanical & 588 & 1.4 & 54 \\
\hline Total & & 1450 & & 54 \\
\hline
\end{tabular}

We use the following Neyman optimum allocation procedure for the stratified random sampling procedure which is as follows:

$$
n_{h}=n *\left[\left(N_{h} * \sigma_{h}\right)\right] /\left[\Sigma\left(N_{i} * \sigma_{i}\right)\right]
$$

Where $n_{h}$ denotes the $h^{\text {th }}$ stratum sample size, $N_{h}$ denotes population size of the $h^{\text {th }}$ 
stratum and $\sigma_{h}$ is the standard deviation of the $h^{\text {th }}$ stratum. Using formula, we get sample size $n=\Sigma n_{h}$. The values of $N_{h}$ and sh (the estimation of $\sigma_{h}$ ) from a pilot study are given in Table 2. The sample values for the graduate employees, principals and industrial employers are given in Tables $2,3, \& 4$.

The universe (Population) for group II is defined as all the students who graduated from GCTs in Punjab in a five years period ranging from 2012-2016, in five technologies falling under the category of Diploma in Associate Engineers (DAEs) and who subsequently got employed in the industries. The said population is divided into subgroups or strata according to technologies. The sample size, calculated for group II is 54 according to the formula given above. A sample size particularly in cases of stratified sampling design yields better results as it can reduce costs and incorporate precision, particularly when the population is geographically dispersed and the strata are sufficiently homogenous (Cohen et al., 2011).

The frame for the survey is developed by obtaining list of TEVTA graduates who are employed in the industries. The sampling frame is divided into strata according to the stratification variables, creating a separate sampling frame for each stratum. Keeping in view the sample size, the sampling units are selected from each group using proportionate stratified sampling technique to avoid under coverage. Targeted numbers of elements are then randomly selected from each stratum. The selection proportions and the frequency of elements are given in Table 2.

Table 3. Sample Selection of Industrial Employers

\begin{tabular}{|c|c|c|c|c|c|c|}
\hline \multirow[t]{2}{*}{ S\# } & \multirow{2}{*}{$\begin{array}{l}\text { Trade (DAE) of } \\
\text { Industries }\end{array}$} & \multirow{2}{*}{$\begin{array}{c}\text { Total No. of } \\
\text { Industries } \\
N_{h}\end{array}$} & \multicolumn{2}{|c|}{$\begin{array}{l}\text { Industries where TEVTA } \\
\text { Graduates are placed }\end{array}$} & \multicolumn{2}{|c|}{$\begin{array}{l}\text { Proportionate Stratified } \\
\text { Sample }\left(n_{h}\right)\end{array}$} \\
\hline & & & Frequency & Percent & Frequency & Percent \\
\hline 5 & Chemical & 287 & 040 & $11 \%$ & 2 & $10 \%$ \\
\hline 4 & Civil & 232 & 089 & $25 \%$ & 5 & $25 \%$ \\
\hline 3 & Electrical & 225 & 104 & $30 \%$ & 6 & $30 \%$ \\
\hline 2 & Electronics & 058 & 033 & $10 \%$ & 2 & $10 \%$ \\
\hline 1 & Mechanical & 238 & 084 & $24 \%$ & 5 & $25 \%$ \\
\hline Total & & 1040 & 350 & $100 \%$ & 20 & $100 \%$ \\
\hline
\end{tabular}

The TVET graduates are placed in 350 industries out of 1040 industries from amongst the five technologies of these institutions (Table 3). Keeping in view the percentage of representation, approximately the same sampling fraction is used for all the strata for sampling out industrial employers. The list of all the industries is defined as the frame for the population for group III, and with the decided sample size of 20, the sampling units i.e. the HR managers from all the five strata are selected randomly. The sample size of each stratum is calculated using the proportionate stratified sampling technique. 


\subsection{Sample Selection of Principals}

Table 4. Sample Selection of the Three Stakeholders

\begin{tabular}{c|c|c|c|c|c|c|c}
\hline S\# & $\begin{array}{c}\text { Trade } \\
\text { (DAE) } \\
\text { of } \\
\text { Employees }\end{array}$ & $\begin{array}{c}\text { Total } \\
\text { number of } \\
\text { institutions }\end{array}$ & $\begin{array}{c}\text { Calculated } \\
\text { sample size } \\
\text { of principals }\end{array}$ & $\begin{array}{c}\text { No. of } \\
\text { Industries } \\
\text { where TVET } \\
\text { Graduates } \\
\text { employed }\end{array}$ & $\begin{array}{c}\text { Calculated } \\
\text { sample } \\
\text { size of } \\
\text { employers }\end{array}$ & $\begin{array}{c}\text { Total } \\
\text { Number of } \\
\text { Graduates } \\
\text { Working } \\
\text { in Industry }\end{array}$ & $\begin{array}{c}\text { Calculated } \\
\text { Sample } \\
\text { Size of } \\
\text { Employees }\end{array}$ \\
\hline 1 & Chemical & 4 & 1 & 040 & 2 & 047 & 03 \\
\hline 2 & Civil & 6 & 1 & 089 & 5 & 251 & 09 \\
\hline 3 & Electrical & 7 & 1 & 104 & 6 & 516 & 18 \\
\hline 4 & Electronics & 7 & 1 & 033 & 2 & 048 & 04 \\
\hline 5 & Mechanical & 6 & 1 & 084 & 5 & 588 & 20 \\
\hline \multicolumn{2}{l}{ Total } & 30 & 5 & 350 & 20 & 1450 & 54 \\
\hline
\end{tabular}

There are 30 government institutions i.e. Government Colleges of Technologies (GCTs) which offer DAEs in the five technologies. These GCTs are sufficiently homogenous in terms of infrastructure, size, quality of education offered, policies, rules and regulations. To draw sample from this target population, we adopted homogeneity based sampling technique. This technique can be used if little variation can exist in given population (Saunders et al., 2016). A sample size of 5 is considered to be sufficient for the research objectives. Hence one institution is selected at random for the interview of the principals (Table 4).

\subsection{Developing Questionnaires}

In view of the objectives of this research, separate questionnaires are developed, tested and validated for three stakeholders namely employers, TVET graduates and principals of institution. Due care needed to be taken as the study is exploratory in nature, particularly in Pakistani context. Primary help is sought from the literature and the pilot study and a rough draft is then presented to experts in the field of TVET and in higher education. The experts are principals of TVET institutions, one senior professor and two industrial experts comprising of an employer and a supervisor. Questionnaires are improved in the light of the feedback provided by the experts. The comments of the experts are related to the content, logical sequence and simplification of language, keeping in view the level of understanding of the respondents.

\subsection{Data Collection}

The respondents' groups are contacted according to pre-set or pre-arranged appointments, to avoid inconvenience. 
Table 5. Populations and Sample Size of the Respondents

\begin{tabular}{|c|c|c|c|c|c|c|c|c|}
\hline \multirow[b]{2}{*}{ S\# } & \multirow[b]{2}{*}{$\begin{array}{c}\text { Trade } \\
\text { (DAE) } \\
\text { of } \\
\text { Employees }\end{array}$} & \multirow[b]{2}{*}{$\begin{array}{c}\text { Total } \\
\text { number of } \\
\text { institutions }\end{array}$} & \multirow[b]{2}{*}{$\begin{array}{c}\text { Total } \\
\text { Number } \\
\text { of } \\
\text { Graduat } \\
\text { es of } \\
2012-20 \\
16\end{array}$} & \multirow[b]{2}{*}{$\begin{array}{l}\text { Total } \\
\text { Number } \\
\text { of } \\
\text { Graduate } \\
\text { s } \\
\text { Working } \\
\text { in } \\
\text { Industry }\end{array}$} & \multirow[b]{2}{*}{$\begin{array}{c}\text { No. of } \\
\text { Industries } \\
\text { where } \\
\text { TVET } \\
\text { Graduate } \\
\text { s } \\
\text { Employe }\end{array}$} & \multicolumn{3}{|c|}{ Sample size of the Respondents } \\
\hline & & & & & & $\underset{\text { Principals }}{\text { Group I }}$ & $\begin{array}{c}\text { Group II } \\
\text { TVET } \\
\text { Graduate } \\
\text { Employees }\end{array}$ & $\begin{array}{l}\text { Group III } \\
\text { Industrial } \\
\text { Employers }\end{array}$ \\
\hline 1 & Chemical & 4 & 3871 & 047 & 040 & 1 & 03 & 5 \\
\hline 2 & Civil & 6 & 15348 & 251 & 089 & 1 & 09 & 6 \\
\hline 3 & Electrical & 7 & 23745 & 516 & 104 & & 18 & 2 \\
\hline 4 & Electronics & 7 & 15129 & 048 & 033 & 1 & 04 & 5 \\
\hline 5 & Mechanica & 6 & 13335 & 588 & 084 & 1 & 20 & 2 \\
\hline & Total & 30 & 71428 & 1450 & 350 & 5 & 54 & 20 \\
\hline
\end{tabular}

\section{Data Analysis}

Table 6. Hiring Mode of TEVT Graduates

\begin{tabular}{l|c|c}
\hline \multicolumn{1}{c|}{ Hiring Modes } & Industrial Employers & Graduates \\
\hline $\begin{array}{l}\text { Through the TEVT } \\
\text { institution }\end{array}$ & $5 \%$ & $19 \%$ \\
\hline Advertisement & $75 \%$ & $11 \%$ \\
\hline Reference & $20 \%$ & $70 \%$ \\
\hline Total & $100 \%$ & 100.0 \\
\hline
\end{tabular}

The data is analyzed by using SPSS 16.0 software. The analysis suggests that $70 \%$ graduates got jobs by using personal references and $11 \%$ are hired through advertisement. Only 19\% graduates are referred by the TVET institute. This shows there is formal setup at institution level partially helpful for their vocational guidance. As per $75 \%$ of the industrial employers, they usually adopt advertisement for hiring purposes and $20 \%$ through personal contact of HR manager of employers. Only in 5\% cases, the skilled force is directly recruited from the institutions (Table 6). Our analysis suggests that had there been a vocational guidance system, both the parties would have had a common platform and hiring would have been quicker and convenient.

Table 7. Linking Strategies

\begin{tabular}{c|l|c|c|c|c}
\hline S\# & \multicolumn{1}{|c|}{ Linking Strategies } & Disagree & Partially agree & Agree & $\begin{array}{c}\text { Strongly } \\
\text { agree }\end{array}$ \\
\hline 1. & Practical on job training contracts & $0 \%$ & $4 \%$ & $13 \%$ & $83 \%$ \\
\hline 2. & Apprenticeship contracts & $0 \%$ & $7 \%$ & $50 \%$ & $43 \%$ \\
\hline 3. & $\begin{array}{l}\text { Visiting demonstrators \& feedback } \\
\text { from relevant industry }\end{array}$ & $4 \%$ & $4 \%$ & $46 \%$ & $46 \%$ \\
\hline 4. & $\begin{array}{l}\text { Career Counseling/placement } \\
\text { System acting as an intermediary }\end{array}$ & $0 \%$ & $2 \%$ & $6 \%$ & $92 \%$ \\
\hline 5. & $\begin{array}{l}\text { institution- relevant industry } \\
\text { Affiliation }\end{array}$ & $7 \%$ & $34 \%$ & $35 \%$ & $24 \%$ \\
\hline
\end{tabular}

The graduate employees expressed their opinions on linking strategies that could produce better employment prospects. Opinion on all five 'linking strategies' are measured using a four point likert scale, ranging from $1=$ 'Disagree' to $4=$ 'Strongly agree'. The graduates are asked if the presence of the linking strategies would have made their job hunt easier. The data 
on five linking strategies show that $92 \%$ and $83 \%$ of the respondents strongly agree that strengthening of career counseling/placement systems by the institutions and beforehand practical on-job training contracts would make it easy for them to find employment (Table 7).

Table 8. Mean Scores of Linking Strategies

\begin{tabular}{l|c|c|c|c|c|c}
\hline $\begin{array}{c}\text { Respondent } \\
\mathrm{s}\end{array}$ & $\begin{array}{c}\text { Apprentice } \\
\text { ship ( } \\
\text { Contracts }\end{array}$ & $\begin{array}{c}\text { Institutio } \\
\mathrm{n}- \\
\text { Relevant } \\
\text { Industry } \\
\text { Affiliatio } \\
\mathrm{n}\end{array}$ & $\begin{array}{c}\text { Visiting } \\
\text { Demonstrators \& } \\
\text { Feedback from } \\
\text { Relevant Industry }\end{array}$ & $\begin{array}{c}\text { Career } \\
\text { Counseli } \\
\text { ng/ } \\
\text { Placemen } \\
\text { t System }\end{array}$ & $\begin{array}{c}\text { On Job } \\
\text { Training } \\
\text { Contracts }\end{array}$ & $\begin{array}{c}\text { Over } \\
\text { all } \\
\text { Linki } \\
\text { ng } \\
\text { Strate } \\
\text { gies }\end{array}$ \\
\hline All & 3.4 & 2.8 & 3.4 & 3.9 & 3.8 & 3.5 \\
\hline Chemical & 4.0 & 3.0 & 2.3 & 4.0 & 3.7 & 3.5 \\
\hline Civil & 3.2 & 2.8 & 3.4 & 3.8 & 3.8 & 3.5 \\
\hline Electrical & 3.1 & 2.6 & 3.3 & 3.9 & 3.8 & 3.4 \\
\hline Electronics & 3.8 & 3.2 & 3.0 & 4.0 & 3.9 & 3.6 \\
\hline Mechanical & 3.4 & 2.8 & 3.6 & 3.9 & 3.8 & 3.5 \\
\hline $\begin{array}{l}\text { Total Mean } \\
\text { of mean } \\
\text { Scores }\end{array}$ & 3.5 & 2.9 & 3.1 & 3.9 & 3.8 & 3.5 \\
\hline
\end{tabular}

The mean scores of the segregated data also show that career counseling/job placement system based on an intermediary agency with a mean score of 3.9 is considered the most important predictor of easier job hunt (Table 8).

Table 9. Correlation between Linking Strategies and Ease of Finding Employment Correlations

\begin{tabular}{l|l|c|c}
\hline & & $\begin{array}{c}\text { Linking } \\
\text { Strategies }\end{array}$ & $\begin{array}{c}\text { Ease in } \\
\text { finding } \\
\text { employment }\end{array}$ \\
\hline \multirow{2}{*}{$\begin{array}{l}\text { Linking } \\
\text { Strategies }\end{array}$} & Pearson Correlation & 1 & \\
\cline { 2 - 4 } & Sig. (2-tailed) & & \\
\cline { 2 - 4 } & $\mathrm{N}$ & 54 & \\
\hline \multirow{2}{*}{$\begin{array}{l}\text { Ease in finding } \\
\text { employment }\end{array}$} & Pearson Correlation & .300 & 1 \\
\cline { 2 - 4 } & Sig. (2-tailed) & .028 & 54 \\
\cline { 2 - 4 } & $\mathrm{N}$ & 54 & 54 \\
\hline
\end{tabular}

*. Correlation is significant at the 0.05 level (2-tailed).

The correlation matrix below shows a positive association between the overall linking strategies and Ease in finding employment, with Pearson's correlation coefficient $=.300$ at .028 which is significant at 0.05 level (2-tailed) (Table 9).

Table 10. ANOVA ${ }^{\mathrm{a}}$

\begin{tabular}{l|c|c|c|c|c|c}
\hline \multicolumn{2}{c|}{ Model } & $\begin{array}{c}\text { Sum of } \\
\text { Squares }\end{array}$ & Df & $\begin{array}{c}\text { Mean } \\
\text { Square }\end{array}$ & F & Sig. \\
\hline \multirow{2}{*}{1} & Regression & .787 & 1 & .787 & 5.136 & $.028^{\mathrm{b}}$ \\
\cline { 2 - 7 } & Residual & 7.972 & 52 & .153 & & \\
\cline { 2 - 7 } & Total & 8.759 & 53 & & & \\
\hline
\end{tabular}

a. Dependent Variable: Ease in finding employment 
b. Predictors: (Constant), Lin king Strategies

In addition to this, the regression model is found significant with Beta coefficient $=.300$ at $p$ $=.028$, which shows that existence of linking strategies can significantly impact and make the job hunt easier (Table 10).

Table 11. Regressions between Linking Strategies and Ease of Finding Employment Coefficients

\begin{tabular}{|c|c|c|c|c|c|c|}
\hline \multirow{2}{*}{\multicolumn{2}{|c|}{ Model }} & \multicolumn{2}{|c|}{$\begin{array}{l}\text { Unstandardized } \\
\text { Coefficients }\end{array}$} & \multirow{3}{*}{$\begin{array}{c}\begin{array}{c}\text { Standardize } \\
\mathrm{d} \\
\text { Coefficients }\end{array} \\
\text { Beta }\end{array}$} & \multirow{3}{*}{$\begin{array}{c}\mathrm{T} \\
.202\end{array}$} & \multirow{3}{*}{$\begin{array}{l}\text { Sig. } \\
.841\end{array}$} \\
\hline & & $B$ & Std. Error & & & \\
\hline \multirow[t]{2}{*}{1} & (Constant) & .147 & .730 & & & \\
\hline & $\begin{array}{c}\text { Linking } \\
\text { Strategies }\end{array}$ & .473 & .209 & 300 & $\begin{array}{c}2.26 \\
6 \\
\end{array}$ & .028 \\
\hline
\end{tabular}

a. Dependent Variable: Ease in finding employment

Table 12. Ranked Linking Strategies

\begin{tabular}{c|c|c|c|c|c}
\hline S\# & Linking Strategies & $\begin{array}{c}\text { Group } \\
\text { I }\end{array}$ & $\begin{array}{c}\text { Group } \\
\text { II }\end{array}$ & $\begin{array}{c}\text { Group } \\
\text { III }\end{array}$ & $\begin{array}{c}\text { Mean of } \\
\text { means }\end{array}$ \\
\hline 1 & $\begin{array}{c}\text { Career Counseling/placement System acting } \\
\text { as an intermediary }\end{array}$ & 3.4 & 3.9 & 3.3 & 3.6 \\
\hline 2 & On Job Training & 3.0 & 3.8 & 3.4 & 3.4 \\
\hline 3 & $\begin{array}{c}\text { Institutions-Industries'(Feedback and } \\
\text { financial) Affiliation }\end{array}$ & 3.6 & 2.9 & 3.1 & 3.2 \\
\hline 4 & Apprenticeship & 3.12 & 3.5 & 2.6 & 3.1 \\
\hline 5 & $\begin{array}{c}\text { Visiting demonstrators \& feedback from } \\
\text { relevant industries }\end{array}$ & 3.2 & 3.1 & 2.3 & 2.9 \\
\hline
\end{tabular}

Ranking the linking strategies by combining the mean scores of all the three groups of respondents shows that Career Counseling/placement System by the Institution is the most prominent of all the strategies with a mean score of 3.6 followed by on-job training with a mean score of 3.4, and Institutions-Industries' (Feedback and financial) Affiliation has taken the third place with a mean score of 3.2 (Table 12).

Table 13. Odds Ratio Analysis

\begin{tabular}{c|c|c|c|c|c}
\hline & $\begin{array}{c}\text { Not easy to find } \\
\text { Employment }\end{array}$ & $\begin{array}{c}\text { Easy to find } \\
\text { Employment }\end{array}$ & $\begin{array}{c}\text { Not Timely/ } \\
\text { Delayed }\end{array}$ & Timely & $\mathrm{N}$ \\
\hline Other Means & 37 & 7 & 23 & 21 & 44 \\
\hline $\begin{array}{c}\text { Through } \\
\text { Counselors }\end{array}$ & 6 & 4 & 4 & 6 & 10 \\
\hline & 43 & 11 & 27 & 27 & 54 \\
\hline Odds ratio & \multicolumn{2}{|c|}{3.5238} & \multicolumn{3}{c}{0.4065 to 6.6398} \\
\hline 95\% CI & 0.7854 to 15.8100 & \multicolumn{3}{c}{0.697} \\
\hline z statistic & \multicolumn{2}{c|}{1.645} &
\end{tabular}

The top ranking of the counselors/placement systems is further supported by the odds ratio analysis according to which, presence of a counselor/placement system makes it 1.6 times earlier and 3.5 times easier for the graduates to find employment (Table 13). 


\section{Discussion}

The goal of this research is to examine the impact of career counseling on employment of graduates in TVET sector. This is an important topic in the context of contributing towards economy of a poor country by developing competitive and market oriented skilled human resource (Moses et al., 2017). Our findings show that graduates of TVET sector in Pakistan are not properly counseled at their respective institute and majority of them are employed without the assistance of their institute. Had they been properly guided during the course of their study, the gap after their graduation and finding job could have been reduced. Therefore, the implications of the concept of career counseling in Pakistan context is more valuable where the majority of intakes in TVET institutes belong to lower strata of the society. The majority of the families of these trainees are illiterate or with low education. They find it difficult to guide the next generation because of their lack of knowledge about vocational profession. The existence of a system of career counseling in turn can help in developing breadth and depth of the area.

This can ultimately result in more absorption of the graduates. The institutionalization of formal career counseling in TVET sector may help Pakistan to boost its economy by producing knowledge based and market oriented skilled workforce. The learning can further be ensured through empirical validation from developed and under developed economies of the world.

\section{Limitations \& Future Research}

The research herein has new insight into the application of impact of career counseling on employment of TVET graduates in the job market. The limitations of this research may lead to opportunities for future researchers. This research has focused on the implications of career counseling in Technology in TVET sector in Punjab which can further be extended to Pakistan or vocational skills. The research cannot be generalized to general education without further empirical validation. In future research, the concept of career counseling can further be explored by elaborating its other aspects. Its empirical studies can be carried out in other provinces of the country or in the private sector institutions of TVET sector. The study can also be made for secondary school graduates going to the labor market or general education in colleges and universities. A comparative study of the career counseling with regard to population trend can be an interesting area, as we have countries with emerging growing population, static population or declining population. Other demographic, social and economic variable with career counseling can enrich our understanding of the career counseling.

\section{Conclusion}

The results of this research shows that career counseling is found to be important in understanding and exploring personal beliefs, goals, career choices, interest and job-finding skills of the students. However, they have reported that their information on career counseling is poor. As a result, the students are unable to find venues from where to obtain career-related information, resulting in lack of future direction and significant decrease in performance. The career counseling and vocational guidance services offered in the TVET institutes in Pakistan 
are not enough and also not strong enough to provide suitable information about the features of different vocational fields, labor market information, and skills required by employers. Career counseling and vocational guidance services through traditional consultancy services from parents, elders and peers may lead trainees to make irrational choices. However, a formalized career counseling services should assist the students to provide necessary information about the course/technology and professions. This would also guide the institutes to include the skills in training program about world of work, labor market information and relevant information about abilities and skills.

Career counseling services are relevant in assisting learners to identify job opportunities and job availabilities in the area of their studies and empower them to utilize their time effectively in training for vocations to which they have tendencies. By contrast, the study reveals that career counseling and vocational services are not given adequately by the parent institutions. Therefore, the availability of the services is not sufficient as per market requirement.

\section{Acknowledgment}

This research was supported by the Principals of Govt. Colleges of Technology, Railway Road, Lahore, Raiwind Road, Lahore, Multan, Faisalabad and Sialkot, functioning under the administrative control of Punjab Technical Education and Vocational Training Authority and 20 HR managers of manufacturing industries in Punjab, Pakistan. We are thankful to our colleagues Mr. Aamir Hussain, Mr. Nayyer Abbas, Mr. Rabi-Bin-Hassan and Mr. Ahmad Shoiab Islam who provided expertise that greatly assisted in the research. We are also grateful to Dr. Mumtaz Muhammad Khan for guidance, and significant improvement in the manuscript.

\section{References}

AGR. (2007). Graduate recruitment survey. Wikipedia.

Aluko, Y. A., \& Aluko, O. (2012). Human Capital Development: Nigeria's Greatest Challenge. Journal of Management, 13(1), 163-170.

Anindo, I., Mugambi, M., \& Matula, D. (2016). Training Equipment and Acquisition of Employable Skills by Trainees in Public Technical and Vocational Education and Training Institutions in Nairobi County, Kenya. Training, 3(4), 103-110.

Ansah, K. S., \& Ernest, K. (2013). Technical and vocational education and training in Ghana: A tool for skill development and industrial development. Journal of Education and Practice, 4(16), 172-180.

Arulmani, G., Bakshi, A. J., Flederman, P., \& Watts, A. G. (2011). Editorial. International Journal for Educational and Vocational Guidance, 11(2), 61-64. https://doi.org/10.1007/s10775-011-9204-5

Asunsung, A. A., Zaato, G. S., \& Owusu, J. (2013). Evaluation of enterprise training on youth employment within the Kumasi Metropolis of Ghana. International Journal Business and Social Research, 3(8), 66-74. 
Atchoerena, D., \& Delluc, A. (2001). Revisiting Technical and Vocational Education in Sub Saharan Africa: An update on trends innovations and challenges. Ishington, District of Columbia: World Bank. [Online] Available: http://unesco.org/llep.

Bilal, A., \& Malik, R. K. (2014). Career Counseling in Pakistan. Choice, 4(16), 1-12.

Brown, A., Bimrose, J., Barnes, S. A., \& Hughes, D. (2012). The role of career adaptabilities for mid-career changers. Journal of Vocational Behavior, 80(3), 754-761. https://doi.org/10.1016/j.jvb.2012.01.003

Cohen, L., Manion, L., \& Morrison, K. (2011). Research Methods in Education. Routledge Publisher, (Chapter 4).

de Guzman, A. B., \& Choi, K. O. (2013). The relations of employability skills to career adaptability among technical school students. Journal of Vocational Behavior, 82(3), 199-207. https://doi.org/10.1016/j.jvb.2013.01.009

Doody, O., \& Doody, C. M. (2015). Conducting a pilot study: case study of a novice researcher. British Journal of Nursing, 24(21), 1074-1078. https://doi.org/10.12968/bjon.2015.24.21.1074

Getachew, A., \& Gobena, D. (2016). "Career Development among Undergraduate Students of Madda Walabu University, South East Ethiopia". Journal of Student Affairs in Africa, 4(2), 25-37.

Hundley, V., \& Van T. E. (2002). The role of pilot studies in midwifery research. $R C M$ midwives: the official journal of the Royal College of Midwives, 5(11), 372-374.

Kim, Y. (2011). The pilot study in qualitative inquiry: Identifying issues and learning lessons for culturally competent research. Qualitative Social Work, 10(2), 190-206. https://doi.org/10.1177/1473325010362001

Kok, J. K., \& Low, S. K. (2017). Proposing a collaborative approach for school counseling. International Journal of School \& Educational Psychology, 5(4), 1-9. https://doi.org/10.1080/21683603.2016.1234986

Leon, A. C., Davis, L. L., \& Kraemer, H. C. (2011). The role and interpretation of pilot studies in clinical research. Journal of psychiatric research, 45(5), 626-629. https://doi.org/10.1016/j.jpsychires.2010.10.008

Marilyn, C. (2008). Understanding and managing employability in changing career contexts. Journal of European Industrial Training, 32(1), 258-284.

Meijers, F., Kuijpers, M., \& Gundy, C. (2013). The relationship between career competencies, career identity, motivation and quality of choice. International Journal Education Vocational Guidance, 13(1), 47-66. https://doi.org/10.1007/s10775-012-9237-4

Mobley, C., Sharp, J. L., Hammond, C., Withington, C., \& Stipanovic, N. (2017). The Influence of Career-Focused Education on Student Career Planning and Development: A 


\section{Macrothink}

International Journal of Human Resource Studies

ISSN 2162-3058 2018, Vol. 8, No. 1

Comparison of CTE and Non-CTE Students. Career and Technical Education Research, 42(1), 57-75. https://doi.org/10.5328/cter42.1.57

Moses, K. M., Muladi, M., \& Wibawa, A. P. (2017). The Linkage between Vocational Schools and Industries Cooperation a comparison in Developed and Developing Countries. International Conference on Education, 483-492.

Murgor, T. K. (2014). Relationship between technical and vocational acquired skills and skills required in job market; Evidence from TVET Institutes, Uasin Gisho County, Kenya. Journal of Education and Practice, 4(19), 77-83.

Santilli, S., Marcionetti, J., Rochat, S., Rossier, J., \& Nota, L. (2017). Career adaptability, hope, optimism, and life satisfaction in Italian and Swiss adolescents. Journal of Career Development, 44(1), 62-76. https://doi.org/10.1177/0894845316633793

Saunders, M. N., Thornhill, A. \& Lewis, P. (2016). Research Methods for Business Students Pearson Education

Seung, N. (2014). Relationship between TVET System and Employment. New Frontiers of Educational Research, 9(1), 109-125.

Tsitskari, E., Goudas, M., Tsalouchou, E., \& Michalopoulou, M. (2017). Employers' expectations of the employability skills needed in the sport and recreation environment. Journal of Hospitality, Leisure, Sport \& Tourism Education, 20(1), 1-9. https://doi.org/10.1016/j.jhlste.2016.11.002

\section{Copyright Disclaimer}

Copyright for this article is retained by the author(s), with first publication rights granted to the journal.

This is an open-access article distributed under the terms and conditions of the Creative Commons Attribution license (http://creativecommons.org/licenses/by/4.0/). 